\title{
Patriotism, Political Participation and Women's Rights: A Critical Analysis of Nigeria's Fourth Republic
}

\author{
Godwin Ihemeje ${ }^{1}$ \\ ${ }^{1}$ Department of Local Government Studies, Obafemi Awolowo University, Ile-Ife, Nigeria. \\ Correspondence: Godwin Ihemeje, Department of Local Government Studies, Obafemi Awolowo University, \\ Ile-Ife, Nigeria. E-mail Address: nedumgod@gmail.com
}

Received: January 14, 2016 Accepted: February 23, 2016 Online Published: October 30, 2016

doi:10.5539/jpl.v9n9p15

URL: http://dx.doi.org/10.5539/jpl.v9n9p15

\begin{abstract}
Nigeria is known for recognizing and rewarding veritable achievements of her women in different endeavors. Despite their high demonstration of patriotism, the paper argues that attention given to women's political rights is inadequate in Nigeria's fourth democratic republic; resulting to low political participation and poor electoral outcome. This paper relies heavily on secondary sources of data collection and conduct of comparative analysis. It identifies factors influencing low political participation among, and concludes that if those low influencing factors are not effectively addressed, it could weaken their sense of national patriotism in the long run.
\end{abstract}

Keywords: fourth republic, Nigeria, patriotism, political participation, women right

\section{Introduction}

Nigeria's fourth republic is enmeshed with petty feelings about patriotism, political participation and women's rights. These three variables overlap and closely linked to each other. Destroying one for the other is tantamount to destroying all. There is a gradual decline in patriotic sense of women in Nigeria in terms of political participation. Perhaps what patriotism researchers have reached consensus on seems to play out in this context; that a sense of superiority and need better reflect nationalism than patriotism (Karasawa, 2002; Kosterman \& Feshbach, 1989; Mummenday, Klink \& Brown, 2001). Yet such consensus remains malleable and subject to criticisms.

If truly patriotism is the "degree of love for and pride in one's nation" (Kosterman \& Feshbach, 1989: 271), then Nigeria women's sense of patriotism requires a critical investigation due to inept and unstable involvement in political activities. One way to measure or ascertain patriotism is through active political participation. This paper entails an exploration of political participation level of women with specific respect to electoral contest and electoral outcomes that characterize representative democracy since the return to civilian administration in May, 29, 1999.

In its structural form, the paper is divided into five parts. The first part is the introduction, second part focuses on conceptual clarification, third part delves into comparative trajectory of women's political participation in Nigeria's fourth republic, the fourth part examines factor militating against women's political participation and patriotism, and the fifth part is the conclusion.

\section{Conceptual Clarification}

Concepts are identified as the most basic tool science has at its disposal (Dinwerth \& Pattberg, 2006:186). Patriotism, political participation and women right are the concepts in this paper. Thus, this section deals with the discourses of concepts as the foundation of its analysis (Akindele et al, 2012:175; Finnemore \& Sikkink, 1998: 891). Such orientation is informed and compelled by the fact that existential complexities and patriotism notion cannot be isolated from political participation and women rights, particularly when thinking and appraising governance in the Nigerian democratic fourth republic. More than that, the nation's politics is deep-rooted in political participation. In other words, a concept to concept understanding will begin with definition and discussion of patriotism.

\subsection{Patriotism}

There exists a consensus among scholars on the meaning of patriotism as "a deeply-felt and affective attachment 
to one's own nation with the capacity to make sacrifices for its defense" (Conover \& Feldman, 1987:1; Ogwuonuonu, 2012). Enormous discords abound regarding its usage and measurement (Gries et al., 2011; Huddy, 2003; Huddy \& Khatib, 2007; Schwind, 2013).

Nathanson defines patriotism as involving the following for attributes: special affection for one's own country, a sense of personal identification with the country, special concern for the well-being of the country, and willingness to sacrifice to promote the country's food (Nathanson, 1993:34-35).

Patriotism refers to "a devotion to one's country. A patriot further supports and acts in defense of his or her country. The term refers generally to a concept of national loyalty. Its derivative is from the Greek word 'patris', meaning fatherland" (Questia, 2013). In the same vein, it is defined as "love someone has for his or her country and willingness to defend it. And a patriot is a person who loves his country and is ready to defend it against an enemy" (Ogwuonuonu, 2012). The definitions appear to capture most essence of belonging to one country or the other, either through parental citizenship or by naturalization saddled with spirit of devotion given to defend any cause of action or inaction about her.

\subsection{Political Participation}

There is no universally accepted definition for political participation (Uhlaner, 2001). However, political participation is often referred to as "political engagement" or "political involvement in decision making" (Lamprianou, 2013). Political participation refers to "citizen's right to seek to influence public affairs; it can take many forms, the most notable of which is voting in elections, but also including joining a political party, standing as a candidate in an election, joining a non-governmental advocacy group, or participating in a demonstration" (Klein, 2005:1).

\subsection{Women's Rights}

The concept of women's rights is strongly linked to the fundamental human rights. The United Nations conducted a study it tagged women's rights are human rights; it emphasizes equality of both women and men before the law and in different activities (UNHR, 2014). In its 1948 universal declaration of human rights, it clearly documents how:

it proclaimed the equal entitlements of women and men to the rights contained in it, without distinction of any kind, such as sex; that declaration stressed the terms "all human beings" and "everyone" in order to leave no doubt that the universal declaration was intended for everyone, men and women alike (UNHR, 2014:4).

Sequel to the above, human rights, in its universal view refer to "those rights that are considered universal to humanity, regardless of citizenship, residency status, ethnicity, gender, or other considerations" (Head, 2013). The definition submitted by Amnesty International perceives human rights thus:

Human rights are basic rights and freedoms that all people are entitled to, regardless of nationality, sex, national or ethnic origin, race, religion, language or other status...Human rights are protected and upheld by international and national laws and treaties (Amnesty International, 2013).

In a more comprehensive documentation from Scottish perspective, human rights can be described as:

both civil and political rights to include absolute rights such as the rights to life and freedom from torture, inhuman and degrading treatment, as well as limited rights such as the right to liberty, and qualified rights such as the right to respect for private and family life, home and correspondence. They also include so-called "negative obligations," where the State must refrain from interfering with the exercise of those rights as well as "positive obligations", where the State must take positive steps to ensure the realization of those rights (SHRC, 2013:4).

Constitutionally, Chapter 4, Articles 33-46 of the Constitution of the Federal Republic of Nigeria (1999) specifically enshrines the fundamental human rights of all Nigerians. These rights as contained in the constitution are inalienable rights of Nigerians irrespective of age, sex, class, color, ethnic-group or religion. Thus women enjoy equal inalienable rights to participate in politics without any discrimination, fear or intimidation. This is known as political right of women - ability to vote and be voted for.

The United Nations Universal Declaration frowns at discrimination against women. It is however noted that "such discrimination encompasses any difference in treatment on the grounds of sex which: intentionally or unintentionally disadvantages women; prevents society as whole from recognizing women's rights in both the private and the public spheres; and prevents women and fundamental freedoms to which they are entitled" (UNHR, 2014:6). 


\section{Comparative Trajectory: Women's Political Participation in Nigeria's Fourth Republic}

This section attempts a comparative analysis of the political participation level of women since the return to civilian rule in May 29, 1999; while our main focal areas of analysis are the executive and legislative arms of government. The country has experienced uninterrupted democratic transitions for over sixteen years whereby elections were conducted in five major periods: 1999, 2003, 2007, 2011 and 2015 respectively. Given the professional capacity of the electoral umpire, the Independent Electoral Commission (INEC); elections were conducted successively under the leaderships of Justice Ephraim Akpata in 1999, Sir Abel Guobadia in 2003, Professors Maurice Iwu in 2007 and Attahiru Jega in 2010 up till June 30, 2015. The importance of INEC is quite relevant in this analysis because it plays the role of political education, enlightenment, and sensitization, conflict resolutions between/among political parties and above all, conducting elections where women were found to be grossly under-represented, as will be shown in different tables.

Table 1. Distribution of women elected to public office in Nigeria, 1999-2011

\begin{tabular}{|c|c|c|c|c|c|c|c|c|}
\hline \multirow[b]{2}{*}{ Office } & \multicolumn{2}{|c|}{1999} & \multicolumn{2}{|c|}{2003} & \multicolumn{2}{|c|}{2007} & \multicolumn{2}{|c|}{2011} \\
\hline & $\begin{array}{l}\text { Seat } \\
\text { Available }\end{array}$ & $\begin{array}{l}\text { Available } \\
\text { Seat Occupied } \\
\text { by Women }\end{array}$ & $\begin{array}{l}\text { Seat } \\
\text { Available }\end{array}$ & $\begin{array}{l}\text { Available } \\
\text { Seat Occupied } \\
\text { by Women }\end{array}$ & $\begin{array}{l}\text { Seat } \\
\text { Available }\end{array}$ & $\begin{array}{l}\text { Available } \\
\text { Seat Occupied } \\
\text { by Women }\end{array}$ & $\begin{array}{l}\text { Seat } \\
\text { Available }\end{array}$ & $\begin{array}{l}\text { Available } \\
\text { Seat Occupied } \\
\text { by Women }\end{array}$ \\
\hline Presidency & 1 & 0 & 1 & 0 & 1 & 0 & 1 & 0 \\
\hline Senate & 109 & $3(2.8 \%)$ & 109 & $4(3.7 \%)$ & 109 & $9(8.3 \%)$ & 109 & $7(6.4 \%)$ \\
\hline House of Reps & 360 & $7(1.9 \%)$ & 360 & $21(5.8 \%)$ & 360 & $27(7.5 \%)$ & 360 & $25(6.9 \%)$ \\
\hline Governors & 36 & 0 & 36 & 0 & 36 & 0 & 36 & 0 \\
\hline State House of Assembly & 990 & $24(2.4 \%)$ & 990 & $40(3.9 \%)$ & 990 & $57(5.8 \%)$ & 990 & $68(6.9 \%)$ \\
\hline $\begin{array}{ll}\text { Local } & \text { Government } \\
\text { Chairpersons } & \end{array}$ & 710 & $13(1.8 \%)$ & 774 & $15(1.9 \%)$ & 740 & $27(3.6 \%)$ & 740 & - \\
\hline Councilors & 6368 & $69(1.1 \%)$ & 6368 & $267(4.2 \%)$ & 6368 & $235(3.7 \%)$ & 6368 & - \\
\hline
\end{tabular}

Source: Okoronkwo-Chukwu (2013:14)

Table 2. Participation in elections by gender in April 2011 in Nigeria

\begin{tabular}{llll}
\hline \multirow{2}{*}{ Office Contested } & Gender & Total \\
\cline { 2 - 3 } & Female Candidates & 19 & 20 \\
\hline President & 1 & 17 & 20 \\
Vice President & 3 & 340 & 353 \\
Governor & 13 & 289 & 347 \\
Deputy Governor & 58 & 2188 & 2408 \\
House of Reps & 220 & 800 & 890 \\
Senatorial & 90 & & \\
\hline
\end{tabular}

Source: British Council (2012)

Table 3. Statistical trends of women deputy governors in Nigeria, 1999-2015

\begin{tabular}{ll}
\hline Election Period & No. of Women Dep. Governor(s) \\
\hline 1999 & 1 \\
2003 & 2 \\
2007 & 6 \\
2011 & 2 \\
2015 & 4 \\
\hline
\end{tabular}

Source: Author's Compilation 
Tables 1, 2 and 3 illustrate vivid experience of under-representation of the Nigerian women in the electoral process and how they occupy political offices between 1999 and 2015. It is not only alarming but calls for worry why women never attained chief executive positions at the state and federal levels, except at the local government level. The highest they have ever attained are those shown in table 3. Exception with utmost reservation is however drawn to two notable Nigerian women; Mrs Dame Virginia Etiaba and Mrs Patricia Olubunmi Eteh. One, for Mrs. Dame Etiaba to have been democratically elected and sworn in on March, 2006 as Deputy Governor and later sworn in on November 3, 2006 after the impeachment of her boss, Mr. Peter Obi for gross misconduct, is a big plus for her and the Nigerian women (Odunfa, 2006). Nevertheless, Mrs Etieba can be described as a governor of circumstances because the governorship position she attained was not contested for; she was filling a vacuum and it was on an interim service to the people of Anambra State and Nigeria. Two, it is correct that Mrs. Patricia Etteh assumed/became the first female speaker in the fourth republic but the position was short-lived as she resigned due to alleged gross misconducts having spent 176 days in office (Ogunmodede, 2007).

Much has been said about 1999, 2003, 2007 and 2011 elections which recorded huge electoral malpractices, electoral conflicts and marginalization of women in Nigeria while little is said about 2015 elections. 2015 elections revealed a period of worse outing for women in politics in terms of participation and representation in the political history of Nigeria since May, 29, 1999.

In a more recent occurrence, the fact still remains that 2015 election results proved women's participation to have grown from bad to worse; such retrogression in the country's civilian administration led to the growing concern amongst women because the percentage of their participation in elective positions witnessed decline or nose-dived from 2007 to 2011 and now in 2015 (Gabriel, 2015:4).

Specifically, gubernatorial elections were held in 29 states and the representation of women seeking the office of governor and deputy governor were 87 out of 380 candidates $(22.9 \%)$ running for the positions. For the senatorial seats, 122 women out of 747 candidates, representing 16 percent were cleared by the Independent Electoral Commission (INEC) to run in the March 28 and April 28 election of 2015. This result was not any better in the contest for lower chamber of parliament where 267 women out of a total of 1774 candidates who ran for the seats at the House of Representatives, representing 15 percent (Gabriel, 2015:4).

The decline or drop in women representation in 2015 could attributed mainly to inadequate support, poor preparation, insufficient fund, and translated to few female contestants in the March 28 and April 11 general elections. Buttressing this view, a Gender Advisor, Search for Common Ground Nigeria, Ene Ede reported that:

noticeable retrogressions were identified only in the number of candidates who contested March 28 and April 11 Presidential, National, Governorship and State House of Assembly elections; but also with a gender focus...the 2007 and 2011 had better focus on processes, issues and candidacy as it concerns women and other marginalized and excluded groups. Only one female candidate contested the 2015 elections, one main governorship contender and five deputy governorship; and 15 percent of 1,774 House of Representatives and 17 percent of 747 Senate seats. Apart from the processes leading to the selection and nominations to various offices, the election crisis resolution, mediation plat form and structures were gender insensitive (Akor, 2015:1).

Further studies on 2015 polls and outcome reveal that out of current 109 members of the National Assembly, 8 are women form: Northwest (Adamawa State); Southwest (Ekiti, Lagos and Oyo States), Southeast (Anambra State), South-south (Cross River State) (Uzoanya \& Awodipe, 2015:8). This electoral gesture does not only exhibit wide disparity against women rather it failed to capture a geopolitical spread of the women representation by excluding Northcentral and Northeast from law-making body of the country

Worthy of documentation is the participation cum representation on political party basis. Remember that there are 2 dominant parties: APC and PDP. A total of 15 women were elected on the platform of APC and PDP to the lower house of representative; seats are shared in ration 10 to 5, 10 for PDP and 5 goes to APC (Jimoh, 2015). At the executive arm, gubernatorial elections have produced four female deputy governors; they include Oluranti Adebowale (Lagos State), Mrs Yetunde Onanuga (Ogun State), Ipabilo Banigo (Rivers State) and Cecilia Ezeilo (Enugu State) (Uzoanya \& Awodipe, 2015:8).

\section{Factors Influencing Low Level of Women's Political Participation and in Electoral Process in Nigeria's Fourth Republic}

The need to improve the quality and quantity of women participation demands a careful knowledge of the draw-backs. One, various significant factors have been identified to be responsible for participation levels of 
women ranging from gender orientation, education and age (Vecchionne and Caprara, 2009). Corroboratively, Verba et al. (1995) claimed that education is a dynamic predictor of political participation while Conway (2001) stressed that, although gender gaps in political participation are shrinking, male population is still more actively engaged than females.

Two, the role of poor civic engagement is another factor. In a Survey conducted by IFES, it is noted that women consistently report lower rates of participation than man in attending community meetings and visiting a community leader; with results showing that only $39 \%$ of women, compared to $57 \%$ of men have taken part in civic activities in the past while $61 \%$ of women have never taken part in any civic activity to express their views or resolve an issue (IFES, 2015). Three, the passive or spectator nature also affect their level of participation (Okoronkwo-Chukwu, 2013:40). The fourth factor is the timid or reluctant support they get (IFES, 2015). Fifth is incessant resistance from the society through its norms and attitudinal perceptions (IFES, 2015, Okoronkwo-Chukwu, 2013).

\section{Conclusion}

This paper has been able to contribute to politics and legal discourse through its investigation on patriotism, political participation and women's rights in Nigeria's fourth republic. The paper delves into conceptual clarification of major terms used in the paper as well as a comparative analysis of women' $\mathrm{s}$ political participation level with particular reference to representation at the executive and legislative organs since 1999 . Factors affecting low political participation are identified.

The starting point to tackle the dilemma is the home being the first agent of political socialization. The idea of 'catch-them-young' should be encouraged right from family settings and then extend to schools at various levels; whereby the girl-child is given the chance to inculcate and exhibit leadership skills. For example the role of a prefect and participation in unionism at the tertiary institutions should not exclude the females.

Others include more advocacies by the academics and civil society groups, adherence to the practice of affirmative action of 30 and $35 \%$, attitudinal change about cultural and religious beliefs, encouragement from the male folks, correct interpretation of the constitution of Federal Republic of Nigeria about equal gender right to politics, imbibing confidence, shunning political violence and money politics.

It is observed that there is a long way for women's political participation to sojourn in the midst of strong resistance in terms of societal perceptions, customs and belief systems, misinterpretation of constitution and unhealthy cultural practices, education and poor economic-base. They in no small measure contribute to the low level of electoral outcome from the women. Once there is such occurrence women under-representation in decision making is certain. Hence, there is need to review approaches that can increase effective political participation of women and accommodating new proactive measures that will further translate to high patriotism.

\section{Acknowledgements}

The author would like to acknowledge the kind support of the management staff of Obafemi Awolowo University especially the Office of the Vice-Chancellor and the Registry, without them this work could not be accomplished. I would also appreciate profoundly the contribution of the academic and non-academic staff of the Department of Local Government Studies, Obafemi Awolowo University for releasing me to utilize my accumulated annual leave, their collective decision and efforts made this project a reality.

\section{References}

Akindele, S. T., Adeyemi, O. O., \& Aluko, O. A. (2012). Democracy, governance, legislative challenges and impediments in Nigeria, 1999-2011. Journal of Politics and Law, 5(2). http://dx.doi.org/10.5539/jpl.v5n2p175

Akor, O. (2015). How women performed in the 2015 general elections. Daily Trust, April 24.

Amnesty International USA. (2013). Human rights basics. Retrieved November 19, 2015, from http://www.amnestyusa.org/research/human-rights-basics

British Council. (2012). Gender in Nigeria Report. Improving the lives of girls and women in Nigeria Issues, Policies, Action. $2^{\text {nd }}$ Edition.

Conover, P. J., \& Feldman, S. (1987). Memo to NES board of overseers regarding measuring patriotism and nationalism. Retrieved from http://www.icpsr.umich.edu

Constitution of the Federal Republic of Nigeria. (1999).

Conway, M. M. (2001). Women and political participation. Political Science and Politics, 34(2), 231-233. 
http://dx.doi.org/10.1017/S1049096501000385

Dingwerth, K., \& Pattberg, P. (2006). Global governance as a perspective on world politics. Global Governance, $12,186$.

Finnemore, M., \& Sikkink, K. (1998). International norm dynamics and political change. International Organisation 52, 4, Autumn, pp.891. http://dx.doi.org/10.1162/002081898550789

Gabriel, C. (2015, June 19). Electoral positions: Why Nigeria records more women losers than winners. Vanguard.

Gries, P. H., Zhang, Q., Crowson, H. M., \& Cai, H. (2011). Patriotism, nationalism and China's US policy: structures and consequences of Chinese national identity. The China Quarterly, 205, 1-17. http://dx.doi.org/10.1017/S0305741010001360

Head, T. (2013). Definition: human rights. Retrieved November 20, 2015, from http://www.civilliberty.about.com/od/internationalhumanrights/g/Human-Rights.Definition.html

Huddy, L. (2003). Group membership, in-group loyalty and political cohesion. In David, O. Sears, L. Huddy, \& R. Jervis (Eds.), handbook of political psychology (pp. 511-58). New York: Oxford University Press.

Huddy, L., \& Khatib, N. (2007, January). American patriotism, national identity and political involvement. American Journal of Political Science, 51(1), 63-77. http://dx.doi.org/10.1111/j.1540-5907.2007.00237.x

IFES. (2015, March 19). Timid support in Nigeria for women in politics. International Foundation for Electoral Systems.

Jimoh, A. (2015). Women of the $8^{\text {th }}$ National Assembly. Daily Trust, June 6.

Karasawa, M. (2002). Patriotism, nationalism and internationalism among Japanese citizens: An Etic-Emic approach. Political Psychology, 23(4), 645-66. http://dx.doi.org/10.1111/0162-895X.00302

Klein, H. (2005). The right to political participation and the information society. A paper presented at Global Democracy Conference at Montreal, May 29-June 1.

Kosterman, R., \& Feshbach, S. (1989). Toward a measure of patriotic and nationalistic attitudes. Political Psychology, 10(2), 257-74. http://dx.doi.org/10.2307/3791647

Lamprianou, I. (2013). Contemporary political participation research: A critical assessment. Berlin Heidelberg: Springer-Verlag.

Mummenday, A., Klink, A., \& Brown, R. (2001). Nationalism and patriotism: national identification and $\begin{array}{lllll}\text { out-group rejection. British Journal of Social Psychology, 40(1), } & \text { 159-72. }\end{array}$ http://dx.doi.org/10.1348/014466601164740

Nathanson, S. (1993). Patriotism, morality and peace. Lanham: Rowman \& Littlefield

Odunfa, S. (2006). Profile: Nigeria's first female governor. Lagos: BBC News. Monday November 6

Ogunmodede, B. (2007). Like Salisu Buhari, like Patricia Olubunmi Etteh. The Nation. December 31.

Ogwuonuonu, F. E. (2012). Opinion: why the spirit of patriotism is low in Nigeria. National Network for Perfect Truth, 9(17).

Okoronkwo-Chukwu, U. (2013). Female representation in Nigeria: The case of the 2011 general elections and the fallacy of 35\% Affirmative Action. Research on Humanities and Social Sciences, 3(2).

Questia Trusted Online Research. (2013). Patriotism. Retrieved November 20, 2015, from http:www.questia.com/library/politics-and-government/political-science/political-movements/patriotism

Schwind, S. (2013). An American's view of national identity and patriotism in Europe. United States of America: German Marshal Fund of the United States.

Scottish Human Rights Commission, SHRC. (2013). The future of human rights in Scotland. Retrieved November 20, 2015, from http://www-scottishhumanrights.com/news./latestnews/article/futscotpaper2013

United Nations Human Rights, UNHR. (2014). Women rights are human rights. New York \& Geneva: United Nations Publication.

Uzoanya, E. P., \& Awodipe, T. (2015). Nigerian women's score-card in 2015 polls. The Guardian, April 18.

Vecchione, M., \& Caprara, G. U. (2009), Personality determinants of political participation: The contribution of traits and self-efficacy beliefs. Personality and Individual Differences, 46, 497-492. 
http://dx.doi.org/10.1016/j.paid.2008.11.021

Verba, S., Schlozoman, K. L., \& Brady, H. (1995). Voice and equality. Civil voluntarism in America. Cambridge: Harvard University Press.

\section{Copyrights}

Copyright for this article is retained by the author(s), with first publication rights granted to the journal.

This is an open-access article distributed under the terms and conditions of the Creative Commons Attribution license (http://creativecommons.org/licenses/by/4.0/). 